\title{
HUBUNGAN PENGETAHUAN DAN POLA KONSUMSI DENGAN STATUS GIZI PADA MAHASISWA KESEHATAN
}

\author{
Permadina Kanah Arieska, Novera Herdiani \\ Program Studi Kesehatan Masyarakat, Fakultas Kesehatan, Universitas Nahdlatul Ulama Surabaya \\ Kampus B Jl. Jemursari No. 51-57 Surabaya Indonesia \\ Email: permadina.kanah@unusa.ac.id
}

\begin{abstract}
Nutritional status is a condition intent on the degree of physical need for energy and nutrients gained from food intake that physical impact can be measured. Nutritional status is influenced by factors of health status, knowledge, economy, and can also be influenced by consumption patterns. Low knowledge of nutrition can cause nutritional problems and changes in eating habits, and patterns of consumption of nutritious foods in adolescence. The purpose of this study was to analyze the relationship between knowledge and consumption patterns with nutritional status in UNUSA Health Faculty students. This type of research is an analytical survey with a cross-sectional approach. The population in this study were all 6th-semester students of Public Health Study Program and Nutrition Study Program at the Health Faculty of UNUSA. Sampling technique using Purposive Sampling and obtained a sample of 79 students. The instruments in this study were nutrition knowledge questionnaire, consumption pattern with Food Frequency Questionnaire (FFQ), and nutritional status using BMI measurements. Univariate and bivariate data analysis was done using the ChiSquare test with a significance level of $\alpha=0.05$. The results showed that most of the respondents were 21 years old, 46 students (58.20\%). Most of them were female, 65 students (82.30\%). There is a significant relationship between knowledge, consumption patterns with nutritional status in students where $p=0.001$ ( $p<0.05$ ). The conclusion of this study is the lower the student's knowledge about nutrition and the less good the student's consumption pattern, the more likely it is to have a lean or fat nutritional status. A suggestion is that students need to pay attention to eating consumption patterns that are following balanced nutrition to achieve good nutritional status.
\end{abstract}

Keywords: Knowledge, Consumption Patterns, Nutritional Status

\begin{abstract}
ABSTRAK
Status gizi adalah sebuah kondisi yang ditentukan oleh tingkat kebutuhan fisik terhadap energi dan zat-zat gizi yang didapatkan dari asupan makanan dengan dampak fisik yang dapat diukur. Status gizi dipengaruhi oleh faktor status kesehatan, pengetahuan, ekonomi, dan juga dapat dipengaruhi oleh pola konsumsi. Timbulnya masalah gizi dapat disebabkan pengetahuan gizi yang rendah dan juga perubahan kebiasaan makan, serta pola konsumsi makanan bergizi pada masa remaja. Tujuan penelitian ini dilakukan untuk menganalisis hubungan pengetahuan dan pola konsumsi dengan status gizi pada mahasiswa Fakultas Kesehatan UNUSA. Jenis penelitian ini adalah survey analitik dengan pendekatan Cross Sectional. Populasi dalam penelitian ini adalah seluruh mahasiswa semester 6 Prodi Ilmu Kesehatan Masyarakat dan Prodi Gizi Fakultas Kesehatan UNUSA. Purposive Sampling merupakan teknik sampling yang dipilih dalam penelitian ini dengan jumlah sampel yang diperoleh sebesar 79 mahasiswa. Instrumen dalam penelitian ini adalah kuesioner pengetahuan gizi, pola
\end{abstract}


konsumsi dengan Food Frequency Questionnaire (FFQ), dan status gizi menggunakan pengukuran IMT. Analisis data univariat dan bivariat dilakukan dengan menggunakan uji Chi-Square dengan alpha $\alpha=0,05$. Hasil penelitian menunjukkan bahwa sebagian besar responden berumur 21 tahun yaitu 46 mahasiswa $(58,20 \%)$. Sebagian besar berjenis kelamin perempuan, yaitu 65 mahasiswa $(82,30 \%)$. Terdapat hubungan signifikan antara pengetahuan, pola konsumsi dengan status gizi pada mahasiswa dimana $p=0,001(p<0,05)$. Kesimpulan dari penelitian ini adalah semakin rendah pengetahuan mahasiswa tentang gizi dan pola konsumsi mahasiswa yang kurang baik berakibat pada semakin besar kemungkinan seseorang memiliki status gizi kurus. Pola konsumsi makan yang sesuai dengan kondisi remaja/mahasiswa dan juga gizi seimbang perlu diterapkan guna mencapai status gizi yang optimal.

Kata kunci: Pengetahuan, Pola Konsumsi, Status Gizi

\section{PENDAHULUAN}

Status gizi adalah sebuah kondisi yang ditentukan oleh tingkat kebutuhan fisik terhadap energi dan zat-zat gizi yang didapatkan dari asupan makanan dengan dampak fisik yang dapat diukur ${ }^{1}$. Status gizi selain dipengaruhi oleh faktor status kesehatan, pengetahuan, ekonomi, lingkungan dan budaya juga dapat dipengaruhi oleh pola konsumsi energi dan protein $^{2}$. Pengetahuan gizi adalah kemampuan memilih makanan yang merupakan sumber gizi dan keterampilan dalam memilih makanan jajanan yang sehat. Pengetahuan gizi yang rendah menjadi penyebab timbulnya masalah gizi dan perubahan kebiasaan pola makan, serta pola konsumsi makanan bergizi pada masa remaja ${ }^{3}$. Pola konsumsi meliputi aneka jenis dan kuantitas makanan yang dikonsumsi serta frekuensi dan waktu makan yang secara jumlah akan menentukan ukuran tinggi rendahnya makanan yang dikonsumsi ${ }^{4}$.

Menurut data RISKESDAS (2013), Indeks Massa Tubuh (IMT) pada remaja dengan prevalensi gizi kurus sebesar 13,1\% pada lakilaki sedangkan pada perempuan $5,7 \%$. Terjadi peningkatan status gizi pada remaja di Indonesia dari sangat kurus menjadi kurus. Hal ini berbeda dengan prevalensi pada status gizi gemuk. Pada tahun 2010 ada sebesar 1,4\% prevalensi gizi gemuk yang mengalami peningkatan pada sebesar 7,3\% pada tahun 2013. Asupan energi makro yang dibutuhkan oleh tubuh dari pola konsumsi penduduk Indonesia yaitu 40-60\%, energi karbohidrat $5-15 \%$, dan energi protein 25-55\% energi lemak tergantung usia atau tahap tumbuh kembang 5 .

Status gizi remaja merupakan masalah yang perlu mendapatkan perhatian khusus sebab pengaruhnya besar dalam menentukan pertumbuhan dan perkembangan tubuh saat dewasa $^{6}$. Berdasarkan penelitian ${ }^{7}$, menunjukkan bahwa ada hubungan antara status gizi dengan pengetahuan gizi pada mahasiswa TPB Sekolah Bisnis dan Manajemen Institut Teknologi Bandung. Berdasarkan penelitian yang 
dilakukan $^{8}$ pada mahasiswa Universitas Indonesia, diperoleh $15,6 \%$ memiliki Indeks Massa Tubuh lebih besar dari 25 dan sebanyak $53,1 \%$ memiliki tingkat pengetahuan rendah berkaitan dengan nutrisi. Kesimpulan yang diperoleh dalam penelitian tersebut adalah tidak adanya hubungan yang signifikan antara asupan energi dan status nutrisi.

Status gizi merupakan salah satu indikator baik buruknya penyediaan makanan sehari-hari, selain itu juga sebagai bentuk ekspresi dari kondisi keseimbangan yang dipresentasikan dalam bentuk variabel tertentu ${ }^{9}$. Status gizi yang baik digunakan untuk mempertahankan tingkat kesehatan, membantu pertumbuhan masa anakanak, juga mendukung prestasi bagi olahragawan profesional. Secara definisi, remaja merupakan suatu fase antara pubertas dan maturitas penuh (berkisar pada usia 10-21 tahun), pada masa ini terjadi proses pematangan fisik yang mengalami perkembangan dari anakanak menjadi dewasa. Terdapat 3 periode perkembangan remaja, yaitu remaja awal (10-14 tahun), remaja pertengahan (15-17 tahun), dan remaja akhir (18-21 tahun). Mahasiswa dapat dikatakan sebagai remaja, dengan kisaran umur antara 17-22 tahun ${ }^{10}$.

Setidaknya ada 2 teknik yang terkenal untuk menilai status gizi, yaitu ingatan teknik ingatan pangan 24 jam (24-hour food recall) dan Food Frequency Questionare (FFQ). Dari kedua teknik ini akan diperoleh gambaran mengenai pola konsumsi masyarakat yang kemudian diolah sedemikian hingga agar menjadi sebuah kesimpulan yang tepat. Menentukan status kesehatan masyarakat bukan suatu hal yang mudah, perlu ketelitian dan kecermatan dalam melakukan perhitungan. Pengetahuan tentang ilmu gizi dan kesehatan pun menjadi syarat yang utama agar diperoleh hasil yang akurat. Hal lain yang sering dipertanyakan adalah kebenaran data. Kebanyakan data yang diperoleh dari sampel tidak dapat mewakili data yang sesungguhnya, atau dalam kasus lain sering kali sampel tidak serius memberikan data, sehingga hal seperti ini pun dapat mempengaruhi hasil dari sistem yang akan dirancang ${ }^{11}$.

Data tentang frekuensi konsumsi makanan selama periode tertentu seperti hari, minggu, bulan atau tahun dikenal dengan Metode frekuensi makanan. Penelitian epidemiologi sering menggunakan metode ini sebab mampu menemukan kelemahan maupun kelebihan zat gizi mikro (baik mineral maupun vitamin) yang dikaitkan dengan kejadian penyakit tertentu (relative sensitive). Selain itu pertimbangan dari sisi kecepatan, murah, dan juga kemudahan diterapkan dilapangan, membuat metode ini banyak digunakan. Oleh karena itu, peneliti akan mengkaji hubungan pengetahuan dan pola konsumsi dengan status gizi pada mahasiswa Fakultas Kesehatan UNUSA.

\section{METODE PENELITIAN}

Desain penelitian yang digunakan dalam penelitian ini adalah desain penelitian deskriptif, 
yaitu dimana penelitian yang mendeskripsikan atau memaparkan peristiwa urgen yang terjadi pada masa kini dimana fenomena itu terjadi. Pendekatan cross sectional digunakan dalam penelitian ini sebab fokus pada waktu observasi data yang dilakukan satu waktu untuk variabel bebas dan variabel terikatnya. Pada penelitian ini akan mendeskripsikan pengetahuan, pola konsumsi dengan status gizi pada mahasiswa Fakultas Kesehatan UNUSA

Populasi pada penelitian ini adalah seluruh mahasiswa semester 6 Prodi IKM dan Prodi Gizi Fakultas Kesehatan UNUSA. Besar sampel yaitu mahasiswa semester 6 Prodi IKM dan Prodi Gizi Fakultas Kesehatan UNUSA dan memenuhi kriteria inklusi serta eksklusi sejumlah 79 mahasiswa. Purposive Sampling merupakan Teknik pemilihan sampel yang digunakan, teknik ini didasarkan pada suatu hal tertentu yang didesain oleh peneliti, didasarkan ciri atau sifat populasi yang sudah diketahui sebelumnya $^{12}$. Teknik ini biasanya dilakukan karena beberapa pertimbangan, misalnya alasan keterbatasan waktu, tenaga dan dana, sehingga tidak dapat mengambil sampel yang besar dan jauh $^{13}$.

Teknik pengumpulan data pengetahuan menggunakan instrument kuesioner dengan pilihan benar salah. Nilai satu jika menjawab benar dan responden yang menjawab salah akan diberi nilai nol. Uji analisa data yang digunakan adalah uji proporsi. Hasil pengukuran pengetahuan ini akan dibagi menjadi tiga kategori baik, cukup, dan kurang. Kategori baik bila jawaban benar $>75 \%$, cukup bila jawaban benar antara 61-75\%, kategori kurang bila jawaban benar $\leq 60 \%{ }^{13}$.

Pengukuran pola konsumsi diukur dengan formulir food frequency questionnaire (FFQ). Menu makanan yang dikonsumsi mahasiswa dicatat dalam FFQ dan hasilnya akan dibagi menjadi tiga kategori yaitu baik, cukup, dan kurang. Nilai 344 - 452 menunjukkan kategori baik, nilai 236 - 343 menunjukkan kategori cukup, dan nilai 128-235 menunjukkan kategori kurang ${ }^{14}$.

Kategori status gizi kemudian dihitung berdasarkan Indeks Massa Tubuh (IMT), hasilnya akan disesuaikan dengan Tabel status gizi berikut:

Tabel 1. Penilaian Status Gizi

\begin{tabular}{lll}
\hline Kategori & Batasan & IMT \\
\hline Kurus & $\begin{array}{l}\text { Kekurangan berat } \\
\text { badan tingkat berat }\end{array}$ & $<17,0$ \\
\hline & $\begin{array}{l}\text { Kekurangan berat } \\
\text { badan tingkat } \\
\text { ringan }\end{array}$ & $17,0-18,4$ \\
\hline Normal & \multicolumn{1}{c}{ Kelebihan berat } & $18,5-25,0$ \\
\hline Gemuk & $\begin{array}{l}\text { Keanan } \\
\text { badan tingkat } \\
\text { ringan }\end{array}$ & \\
\hline & $\begin{array}{l}\text { Kelebihan berat } \\
\text { badan tingkat berat }\end{array}$ \\
\hline
\end{tabular}

Analisis yang pertama adalah analisis Bivariat (analisis dua variabel yang diduga saling berhunbugan satu sama lain). Analisis bivariate digunakan untuk mengetahui hubungan pengetahuan dan pola konsumsi 
dengan status gizi, menggunakan uji statistik Chi Square.

\section{HASIL DAN PEMBAHASAN}

\section{Hasil Penelitian}

\section{Umur Responden}

Responden dalam penelitian ini adalah mahasiswa semester 6 Prodi Ilmu Kesehatan Masyarakat dan Prodi Gizi Fakultas Kesehatan Universitas Nahdlatul Ulama Surabaya. Jumlah responden dalam penelitian ini adalah 79 mahasiswa. Distribusi frekuensi responden berdasarkan umur dapat dilihat pada Tabel 2.

Tabel 2. Distribusi Frekuensi Responden Berdasarkan Umur

\begin{tabular}{ccc}
\hline Kategori Umur & Frekuensi & Persentase \\
\hline 19 & 5 & 6,30 \\
20 & 24 & 30,40 \\
21 & 46 & 58,20 \\
22 & 4 & 5,10 \\
\hline Total & 79 & 100,00 \\
\hline
\end{tabular}

Sebagian besar responden berumur 21 tahun yaitu 46 mahasiswa $(58,20 \%)$, sedangkan responden dengan umur 22 tahun paling sedikit, yaitu hanya 4 mahasiswa $(5,10 \%)$.

\section{Jenis Kelamin Responden}

Tabel 3. Distribusi Frekuensi Responden Berdasarkan Jenis Kelamin

\begin{tabular}{lcc}
\hline Jenis Kelamin & Frekuensi & Persentase \\
\hline Laki-Laki & 14 & 17,70 \\
Perempuan & 65 & 82,30 \\
\hline Total & 79 & 100,00 \\
\hline
\end{tabular}

Karakteristik responden menurut jenis kelamin terlihat dari Tabel 3. sebagian besar berjenis kelamin perempuan, yaitu 65 mahasiswa (82,30\%). Jika dilihat dari populasinya, memang jumlah mahasiswa lakilaki lebih sedikit dibandingkan dengan jumlah mahasiswa yang berjenis kelamin perempuan.

\section{Pengetahuan Responden}

Pengetahuan responden dapat dilihat pada Tabel 4. sebagai berikut.

Tabel 4. Distribusi Frekuensi Responden Berdasarkan Pengetahuan

\begin{tabular}{lcc}
\hline Tingkat Pengetahuan & Frekuensi & Persentase \\
\hline Baik & 7 & 8,86 \\
Cukup & 40 & 50,64 \\
Kurang & 32 & 40,50 \\
\hline Total & 79 & 100,00 \\
\hline
\end{tabular}

Berdasarkan Tabel 4, ada sebanyak 40 responden $(50,64 \%)$ dengan kategori pengetahuan cukup, kemudian sebanyak 32 responden $(40,50 \%)$ dengan kategori pengetahuan kurang, dan hanya sebesar 7 responden $(8,86 \%)$ memiliki kategori baik. Tingkat pengetahuan baik jumlahnya lebih sedikit dibandingkan dengan kategori tingkat pengetahuan yang lain. Hal ini menandakan bahwa pengetahuan responden tentang konsumsi makanan masih belum optimal. Responden dalam hal ini kalangan mahasiswa (remaja) masih minim pengetahuannya tentang gizi makanan. 


\section{Pola Konsumsi Responden}

Tabel 5. Distribusi Frekuensi Responden Berdasarkan Pola Konsumsi

\begin{tabular}{lcc}
\hline Pola Konsumsi & Frekuensi & Persentase \\
\hline Baik & 30 & 37,97 \\
Cukup & 26 & 32,91 \\
Kurang & 23 & 29,12 \\
\hline Total & 79 & 100,00 \\
\hline
\end{tabular}

Berdasarkan Tabel 5. diperoleh data sebanyak 30 responden $(37,97 \%)$ memiliki pola konsumsi yang baik, kemudian sebanyak 26 responden $(32,91 \%)$ memiliki pola konsumsi dengan kategori cukup, dan sebesar 23 responden $(29,12 \%)$ memiliki pola konsumsi yang kurang.

\section{Status Gizi Responden}

Status gizi responden digambarkan dengan perhitungan Indeks Massa Tubuh (IMT). Kategori status gizi yang digunakan adalah menggunakan standar WHO, dan dikategorikan dalam lima kategori, yaitu gemuk berat, gemuk ringan, normal, kurus ringan dan kurus berat. Status gizi responden dapat dilihat pada Tabel 6.
Tabel 6. Distribusi Frekuensi Responden Berdasarkan Status Gizi

\begin{tabular}{lcr}
\hline \multicolumn{1}{c}{ Status Gizi } & \multicolumn{2}{c}{ Frekuensi Persentase } \\
\hline $\begin{array}{l}\text { Gemuk kelebihan } \\
\text { berat badan tingkat } \\
\text { berat }\end{array}$ & 5 & 6,32 \\
$\begin{array}{l}\text { Gemuk kelebihan } \\
\text { berat badan tingkat } \\
\text { ringan }\end{array}$ & 9 & 11,40 \\
$\begin{array}{l}\text { Normal } \\
\text { Kurus kekurangan } \\
\text { berat badan tingkat } \\
\text { berat }\end{array}$ & 49 & 62,03 \\
$\begin{array}{l}\text { Kurus kekurangan } \\
\text { berat badan tingkat } \\
\text { ringan }\end{array}$ & 14 & 2,53 \\
\hline Total & & 17,72 \\
\hline
\end{tabular}

Berdasarkan Tabel 6. diperoleh data sebagian besar 49 responden $(62,03 \%)$ memiliki status gizi normal. Disamping itu, sebanyak 14 responden $(17,72 \%)$ memiliki status gizi kurus tingkat ringan, 9 responden $(11,40 \%)$ memiliki status gizi gemuk tingkat ringan, 5 responden $(6,32 \%)$ memiliki status gizi gemuk tingkat berat, dan 2 responden $(2,53 \%)$ memiliki status gizi gemuk tingkat berat.

\section{Hubungan Pengetahuan dengan Status Gizi}

Tabel 7. Hubungan Pengetahuan dengan Status Gizi

\begin{tabular}{|c|c|c|c|c|c|c|c|c|c|c|c|c|}
\hline \multirow{3}{*}{$\begin{array}{c}\text { Tingkat } \\
\text { pengetahuan }\end{array}$} & \multicolumn{10}{|c|}{ Status Gizi } & \multirow{2}{*}{\multicolumn{2}{|c|}{ Total }} \\
\hline & \multicolumn{2}{|c|}{$\begin{array}{c}\text { Gemuk } \\
\text { Berat }\end{array}$} & \multicolumn{2}{|c|}{$\begin{array}{l}\text { Gemuk } \\
\text { Ringan }\end{array}$} & \multicolumn{2}{|c|}{ Normal } & \multicolumn{2}{|c|}{ Kurus Ringan } & \multicolumn{2}{|c|}{ Kurus Berat } & & \\
\hline & $\mathrm{n}$ & $\%$ & $\mathrm{n}$ & $\%$ & $\mathrm{n}$ & $\%$ & $\mathrm{n}$ & $\%$ & $\mathrm{n}$ & $\%$ & $\mathrm{n}$ & $\%$ \\
\hline Baik & 0 & 0 & 0 & 0 & 7 & 8,90 & 0 & 0 & 0 & 0 & 7 & 8,90 \\
\hline Cukup & 2 & 2,50 & 1 & 1,30 & 35 & 44,30 & 2 & 2,50 & 0 & 0 & 40 & 50,60 \\
\hline Kurang & 3 & 3,80 & 8 & 10,10 & 7 & 8,90 & 12 & 15,20 & 2 & 2,50 & 32 & 40,50 \\
\hline Jumlah & 5 & 6,30 & 9 & 11,40 & 49 & 62,00 & 14 & 17,70 & 2 & 2,50 & 79 & 100,00 \\
\hline Uji Chi Square & & Hitun & & 5,04 & & abel = & $=30,98$ & & $\mathrm{df}=4$ & & & 0,001 \\
\hline
\end{tabular}


Berdasarkan Tabel 7. diperoleh hasil uji $\mathrm{X}^{2} p=0,001$ sehingga Ho ditolak yang berarti ada hubungan yang signifikan antara pengetahuan gizi dengan status gizi. Pola hubungan antara pengetahuan dengan status gizi menginterpretasikan bahwa semakin rendah pengetahuan tentang gizi akan semakin besar peluang seseorang untuk memiliki status gizi kurus.
Sikap pada seseorang akan muncul diawali adanya pengetahuan yang menurut persepsi baik atau tidak baik, persepsi ini kemudian mengakar dalam dirinya hingga orang tersebut akan bersikap sesuai dengan pengetahuannya. Hal ini dapat menunjukkan bahwa sikap terbentuk dari komponen pengetahuan dan hal ini akan berpengaruh terhadap perilaku seseorang dalam memilih makanan seimbang ${ }^{14}$.

\section{Hubungan Pola Konsumsi dengan Status Gizi}

Tabel. 8. Hubungan Pola Konsumsi dengan Status Gizi

\begin{tabular}{|c|c|c|c|c|c|c|c|c|c|c|c|c|}
\hline \multirow[t]{3}{*}{ Pola Konsumsi } & \multicolumn{10}{|c|}{ Status Gizi } & \multirow{2}{*}{\multicolumn{2}{|c|}{ Total }} \\
\hline & \multicolumn{2}{|c|}{$\begin{array}{c}\text { Gemuk } \\
\text { Berat }\end{array}$} & \multicolumn{2}{|c|}{$\begin{array}{l}\text { Gemuk } \\
\text { Ringan }\end{array}$} & \multicolumn{2}{|c|}{ Normal } & \multicolumn{2}{|c|}{$\begin{array}{l}\text { Kurus } \\
\text { Ringan }\end{array}$} & \multicolumn{2}{|c|}{ Kurus Berat } & & \\
\hline & $\mathrm{n}$ & $\%$ & $\mathrm{n}$ & $\%$ & $\mathrm{n}$ & $\%$ & $\mathrm{n}$ & $\%$ & $\mathrm{n}$ & $\%$ & $\mathrm{n}$ & $\%$ \\
\hline Baik & 1 & 1,30 & 1 & 1,30 & 27 & 34,20 & 1 & 1,30 & 0 & 0 & 30 & 38,00 \\
\hline Cukup & 3 & 3,80 & 5 & 6,30 & 17 & 21,50 & 1 & 1,30 & 0 & 0 & 26 & 32,90 \\
\hline Kurang & 1 & 1,30 & 3 & 3,89 & 5 & 6,30 & 12 & 15,20 & 2 & 2,50 & 23 & 29,10 \\
\hline Total & 5 & 6,30 & 9 & 11,40 & 49 & 62,00 & 14 & 17,70 & 2 & 2,50 & 79 & 100,00 \\
\hline Uji Chi Square & \multicolumn{4}{|c|}{$\mathrm{X}^{2}$ Hitung $=40,84$} & \multicolumn{4}{|c|}{$\mathrm{X}^{2}$ Tabel $=30,98$} & \multicolumn{2}{|c|}{$\mathrm{df}=4$} & \multicolumn{2}{|c|}{$p=0,001$} \\
\hline
\end{tabular}

Berdasarkan Tabel 8. diperoleh hasil uji $\mathrm{X}^{2} p=0,001$ sehingga Ho ditolak, artinya antara pola konsumsi dengan status gizi memiliki hubungan signifikan. Hal ini dapat dijelaskan bahwa semakin baik pola konsumsi makanan mahasiswa maka semakin besar kemungkinan untuk memiliki status gizi dengan kategori yang baik pula. Dari 30 mahasiswa yang memiliki pola konsumsi baik ternyata terdapat 27 responden dengan status gizi normal, 1 responden dengan status gizi gemuk, 1 responden dengan status gizi gemuk ringan, dan status gizi kurus ringan sebanyak 1 responden. Dari 26 mahasiswa yang memiliki pola konsumsi cukup, terdapat 17 responden dengan status gizi normal, 5 responden yang memiliki status gizi gemuk ringan, dan 3 responden dengan status gizi gemuk berat, dan 1 responden memiliki status gizi kurus ringan. Sedangkan 23 mahasiswa yang memiliki pola konsumsi kurang, sebanyak 1 responden memiliki status gizi gemuk berat, 2 responden memiliki status gizi kurus berat, 3 responden memiliki status gizi gemuk ringan, 5 responden memiliki status gizi normal dan ada 12 responden memiliki status gizi kurus ringan.

Status gizi seseorang dianalisis berdasarkan asupan gizi dan kemampuan tubuh 
dalam menyerap zat-zat gizi tersebut. Lingkungan sekitar juga perlu diperhatikan sebab factor ini juga mempengaruhi pola makan remaja. Remaja lebih memilih makanan dengan kandungan natrium dan lemak yang tinggi namun rendah vitamin dan juga mineral. Makanan snack (padat kalori) dan junk food merupakan makanan yang banyak disukai remaja dibanding dengan makanan pokok yang seimbang dan baik dikonsumsi harian. Hal ini menyebabkan tidak terpenuhinya kebutuhan gizi secara optimal pada tubuh remaja.

Selain itu jumlah asupan zat gizi yang tidak cukup juga menjadi faktor penyebab masih adanya kategori status gizi kurus pada mahasiswa. Tren pola diet ketat pada remaja putri juga menjadi factor pendukung jumlah asupan gizi yang tidak cukup pada remaja selain factor kesukaan berlebihan dalam mengonsumsi jajanan/snack dibanding makanan pokok.

Konsumsi karbohidrat, lemak maupun protein yang overload menyebabkan mahasiswa memiliki status gizi berlebih. Tak hanya itu, faktor malas olahraga (kurang bergerak) juga bisa menjadi pemicu menumpuknya makanan didalam tubun yang akhirnya menjadi lemak. Beberapa pola makan yang sudah menjadi kebiasaan mahasiswa hingga mereka mengalami berat badan berlebih antara lain terlalu banyak makan snack, waktu makan yang terlewatkan terutama sarapan pagi, sering mengkonsumsi fast food, makan tidak teratur, konsumsi buah sayur kurang dan banyak konsumsi produk peternakan juga kontrol berat badan yang salah terutama pada remaja putri. Inilah yang mengakibatkan asupan makanan tidak sesuai kebutuhan dan gizi seimbang yang memberikan efek gizi kurang atau lebih ${ }^{4}$.

Kejadian obesitas pada remaja merupakan faktor resiko yang diakibatkan oleh pola konsumsi makanan yang berlebih. Berat badan akan mengalami peningkatan terus menerus dan ini akan dapat membahayakan remaja tersebut. Oleh karena itu perlu diatur pola makan atau pola konsumsi makanan pada saat remaja agar tidak menimbulkan efek lanjutan saat dewasa yang pastinya akan jauh lebih sulit dalam mengontrolnya.

\section{SIMPULAN DAN SARAN}

\section{Simpulan}

Berdasarkan hasil penelitian yang telah dilakukan dapat disimpulkan sebagian besar responden berumur 21 tahun $(58,20 \%)$ dan berjenis kelamin perempuan, $(82,30 \%)$. Ada hubungan yang signifikan antara pengetahuan gizi dengan status gizi pada mahasiswa dan terdapat hubungan signifikan antara pola konsumsi dengan status gizi pada mahasiswa.

\section{Saran}

Saran yang dapat diberikan yaitu untuk penelitian lanjutan dapat dikembangkan tentang faktor lain seperti variabel sosial budaya dan faktor predisposisi yang belum dimasukkan dalam penelitian ini. Pola konsumsi makanan yang sesuai dengan gizi seimbang perlu 
diperhatikan mahasiswa guna tercapai status gizi yang baik, sehingga mendukung tumbuh kembang pada remaja.

\section{REFERENSI}

1. Suhardjo. Perencanaan Pangan dan Gizi. Jakarta: Bumi Aksara. 2008.

2. Ghulam, A. Faktor-faktor yang Berhubungan dengan Pemenuhan Pola Pangan Harapan Ditinjau Dari segi Daya Beli Konsumsi Pangan Tahun 2010. Jakarta: Universitas Muhammadiyah Prof. DR.Hamka. 2010.

3. Notoatmodjo, S. Promosi Kesehatan Teori \& Aplikasi. Jakarta: PT Rineka Cipta. 2010.

4. Islamiyati, A. N. Pengetahuan, Sikap, Tindakan Konsumsi Makanan Dan Minuman Instan Pada Siswa Kelas XII Program Keahlian Jasa Boga Sekolah Menengah Kejuruan Negeri 6 Yogyakarta. Skripsi. Yogyakarta: Pendidikan Teknik Boga Univesitas Negeri Yogyakarta. 2014.

5. Badan Penelitian dan Pengembangan Kesehatan Kementrian Kesehatan RI. Riset Kesehatan Dasar 2013. Jakarta: Kementrian Kesehatan RI. 2013.

6. Anggraeni, M. Pendidikan Gizi Remaja Perkotaan di Daerah Khusus Ibukota Jakarta. Skripsi. Institut Pertanian Bogor. Bogor. 2006.

7. Florence, G. A. Hubungan Pengetahuan Gizi dan Pola Konsumsi Dengan Status Gizi Pada Mahasiswa TPB Sekolah Bisnis dan Manajemen Institut Teknologi Bandung. Tugas Akhir. Bandung: Sekolah Bisnis dan Manajemen ITB. 2017.

8. Sebayang, A. N. Gambaran Pola Konsumsi Makanan Mahasiswa di Universitas Indonesia. Skripsi. Universitas Indonesia. Jakarta. 2012.

9. Irianto, D.P. Panduan Gizi Lengkap Keluarga dan Olahragawan. Yogyakarta. 2006.
10. Indrawagita, L. Hubungan Status Gizi, Aktivitas Fisik dn Asupan Gizi dengan Kebugaran Mahasiswi Program Studi Gizi Fakultas Kesehatan Masyarakat Universitas Indonesia. Skripsi. Jakarta: Universitas Indonesia. 2009.

11. Sugiyono. Metode Penelitian Kuantitatif Kualitatif dan R\&D. Bandung: Alfabeta. 2012.

12. Notoatmodjo, S. Metodologi Penelitian Kesehatan. Jakarta: PT. Rineka Cipta. 2010.

13. Arikunto, S. Prosedur Penelitian: Suatu Pendekatan Praktik. Jakarta: Rineka Cipta. 2013.

14. Suhardjo. Perencanaan Pangan dan Gizi. Jakarta: Bumi Aksara. 2008. 